\title{
Masonry Walls Retrofitting with Eco-Concrete Bricks in Tidal Flooding Prone Area
}

\author{
Rr. M. I. Retno Susilorini ${ }^{1 *}$, Stefanus William $\mathbf{S}^{2}$, Rianto ${ }^{2}$, Silvi Kartikowati ${ }^{2}$, Mohammad Hendri Setiawan ${ }^{2}$, Ludfie \\ Hardian P' ${ }^{2}$, Erik Kurniawan ${ }^{2}$

\begin{abstract}
${ }^{I}$ Department of Infrastructure and Environmental Engineering, Faculty of Environmental Science and Technology, Soegijapranata Catholic University, Jl. Pawiyatan Luhur IV/1, Bendan Dhuwur, Semarang 50234, Indonesia

${ }^{2}$ Department of Civil Engineering, Faculty of Engineering, Soegijapranata Catholic University, Jl. Pawiyatan Luhur IV/1, Bendan Dhuwur, Semarang 50234, Indonesia
\end{abstract}

*Corresponding author: ORCID 0000-0001-8531-7485

\begin{abstract}
Durability of concrete masonry wall in marine environment is a big issue that related to the deterioration of the structure exposed to seawater. Therefore, proper retrofitting should be done effectively to gain high durability of the structure. This research aims to: (1) developed eco-concrete bricks that were implemented to retrofit masonry wall in tidal prone area; and (2) to investigate durability as well as compressive strength development of concrete bricks produced in the laboratory and applied to masonry wall for 14 months. Research activities consisted of: (1) Experimental activities of concrete bricks mix design optimizing, production, and compressive strength test of concrete brick specimens; (2) Field application which consisted of masonry wall retrofitting by eco-concrete bricks, and (3) Core Drill of concrete masonry wall and compressive strength test of the Core Drill specimens. The concrete bricks made of natural polymer such as Moringa oleifera, Gracilaria Sp., and also honey. Masonry walls were built in Sriwulan village as tidal prone area and in Pucang Gading as dry and lowland area. Results have shown that K1K3 series of eco-concrete bricks were the optimum composition with compressive strength of $15.88 \mathrm{MPa}$ and 16.13 MPa. Eco-concrete bricks of K3 series applied to the broken masonry wall for retrofitting. Good performance of compressive strength of Core Drill specimens tested at age 14 month have shown about four times (73.84 MPa) for specimens of Pucang Gading village and about three times (58.61 MPa) of Sriwulan village. Eco-concrete bricks with natural polymers of Moringa oleifera, Gracilaria Sp., and also honey have proven great performance in durability and compressive strength increase.
\end{abstract}

Keywords: concrete, masonry wall, retrofitting, eco-concrete brick, tidal flooding.

\section{INTRODUCTION}

Concrete masonry wall is very popular for housing in urban areas because of its high compressive strength and economic values as well as good insulation, soundness, durability [1][2]. However, the advantage of concrete and also concrete masonry wall meet problems of durability when the concrete structures built in marine environment [3][4], especially tidal prone area. Deterioration of concrete structure such as corrosion of reinforcement, spalling of concrete, aggressive chemical exposure, erosion and abrasion, have become disadvantage to maintain durability of concrete that is exposed to seawater. Hence, it important to develop innovation to achieve better durability of concrete in marine environment.

Durability of concrete brick will be a big issue when the house is submerged incidentally or continuously submerged by seawater. Several researches reported innovation and development in concrete retrofitting in marine environment such as reinforcement to prohibit corrosion, using premixed mortar additive, bonding chemical agent, and applied special threatment for concrete and reinforcement [5-10].

Something we can develop is applying good material that provides high durability for structural concrete. Some natural polymers, or it can be named as "eco-materials", have been developed and used to increase strength and durability of concrete. The using of natural admixture of Gracilaria Sp. and Euchema Cotonii to increase mortar and concrete compressive strength reported by [11]. Previous research has also found the advantage of natural polymer modified concrete with addition of Moringa oleifera [12], while comparison between natural polymer modified concrete and mortar with Moringa oleifera [13] emphasized good compressive strength provided by Moringa oleifera. The addition of honey reported by [14] and proven in increase compressive strength of mortar and concrete.

Many of those efforts in concrete retrofitting and ecomaterials development had been carried out in laboratory and just small amount of action had applied in field. This research wants to bring innovation from laboratory to field application, by develop eco-concrete bricks by addition of natural polymers such as Moringa oleifera, Gracilaria Sp., and also honey which were implemented to retrofit the broken masonry wall in tidal flooding prone area. An advantage should be given by the natural polymers to increase the performance of concrete bricks and concrete masonry wall. A key of the research question which had become aim of this research is to investigate durability as well as compressive strength 
development of concrete bricks produced in the laboratory and applied to masonry wall for 14 months.

\section{MATERIAL AND METHOD}

\section{II.I. Research Stages}

The research conducted in several stages that took several years (2016-2018) to get final results. Main stages consisted of experimental tests in laboratory and also field application. It is obvious that the research brings design and experimental of concrete brick to the application of masonry wall for retrofitting in sites. Stages of the research can be explained as follow: (1) Experimental activities of concrete bricks mix design optimizing, production, and compressive strength test of concrete brick specimens; (2) Field application which conducted masonry wall retrofitting by eco-concrete bricks, and (3) Core Drill of concrete masonry wall and compressive strength test of the Core Drill specimens.

\section{II.II. Site and Situation}

Site for masonry wall construction retrofitting was in Sriwulan village in Sayung sub-district, and also Pucang Gading Village in Batursari sub-district, both were in Demak Regency, Central Java, Indonesia. Sriwulan village (Fig 1) is located in coastal area of Java Sea which is also tidal flooding prone area and Pucang Gading village (Fig 2) is dry and lowland area.

Sriwulan village always be influenced by tidal flooding for more than two decades. This village was located next to the sea and very flat with altitude of 1-3 $\mathrm{m}$ of sea level. The tidal flooding continuously submerged Sriwulan village very badly, from only $25 \mathrm{~cm}$ in 2004 until 20-50 cm in 2018 [1], and even $50-150 \mathrm{~cm}$ as the worst happened on December 1, 2017. This situation was the opposite to Pucang Gading which is dry and clear lowland area with no tidal flooding. A house in Sriwulan village with broken clay brick masonry wall and that hardly submerged with seawater and also routine tidal flooding (Fig 3) was retrofitted by the concrete bricks with natural polymer.

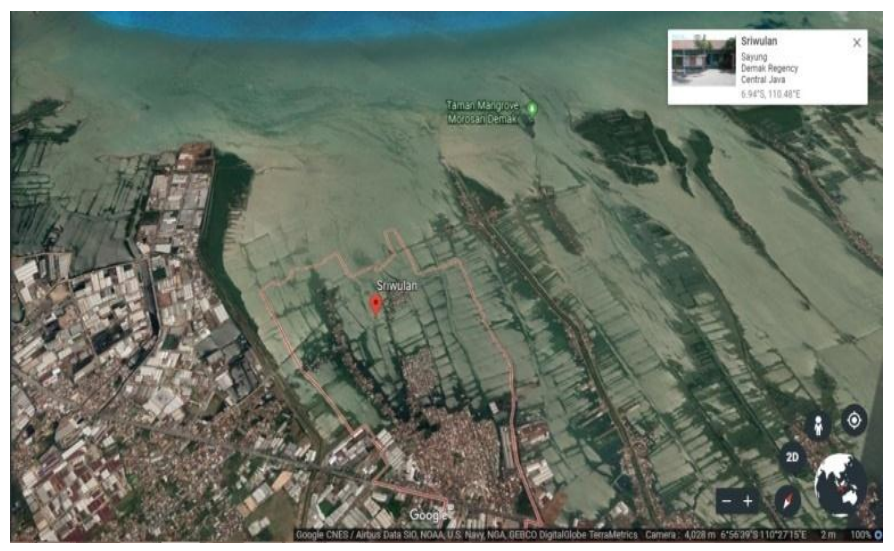

Fig 1. The map of Sriwulan Village in Sayung Sub-district, Demak Regency, Central Java, Indonesia (by Google Earth)

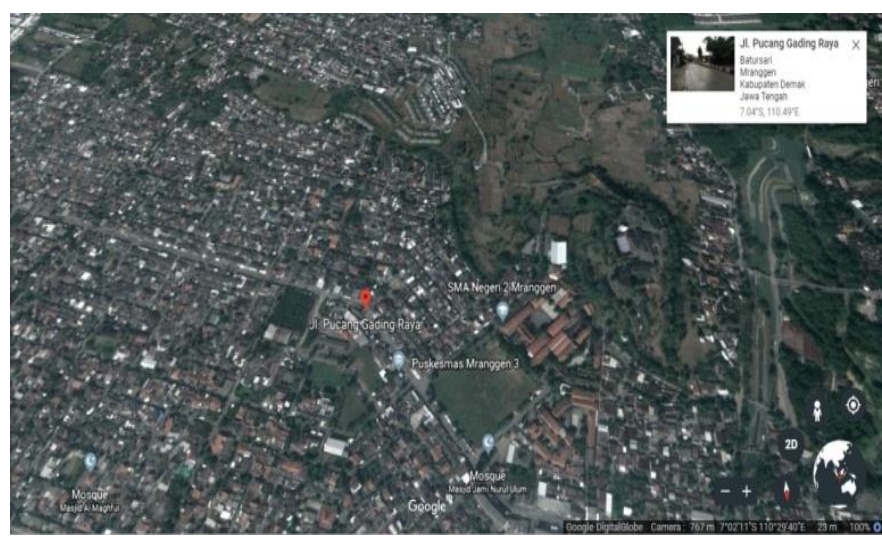

Fig 2. The map of Pucang Gading, Batursari Village, Mraggen Sub-district, Demak Regency, Central Java, Indonesia (by Google Earth)

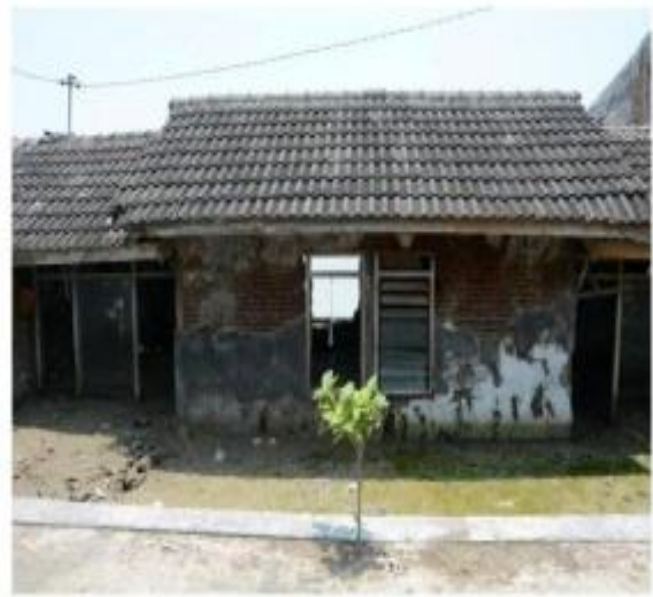

(a)

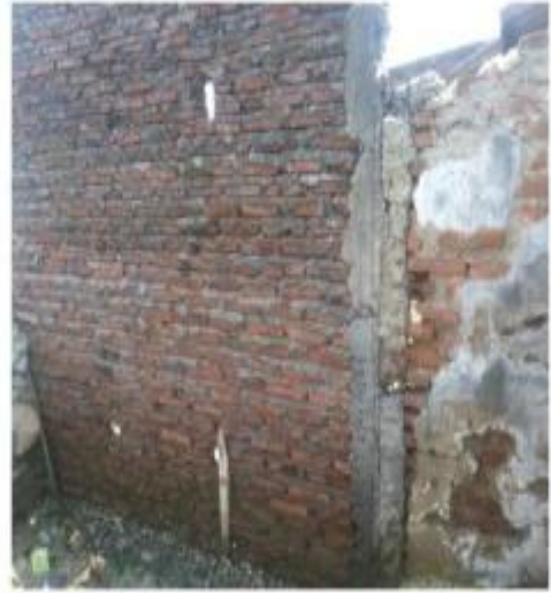

(b)

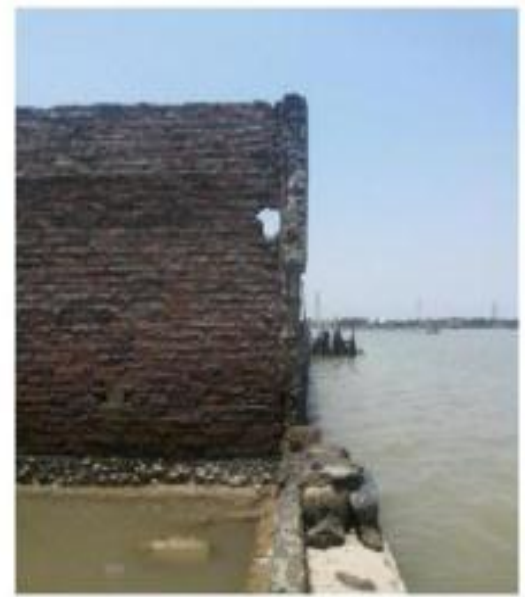

(c)

Fig 3. Situation of the site: (a) a house that directly adjacent to the sea; (b) the broken part of clay brick masonry wall; (c) the area outside the house that submerged by seawater and routine tidal flooding 


\section{EXPERIMENTAL ACTIVITIES}

\section{III.I. Material and Dimension of Brick Specimens}

This research produced 3 (three) types $(\mathrm{A}, \mathrm{B}, \mathrm{C})$ of concrete brick specimens that referred to manufactured products (SL-A, B, C). Dimension of concrete brick specimen was described by Fig 4 while the dimension explained by Table 1 respectively.

Table 1. Dimension of brick specimen and product

\begin{tabular}{|c|c|c|c|}
\hline type & $\mathbf{p}(\mathbf{c m})$ & $\mathbf{l}(\mathbf{c m})$ & $\mathbf{t}(\mathbf{c m})$ \\
\hline $\mathrm{A}$ & 39 & 19 & 9 \\
\hline $\mathrm{B}$ & 37 & 15.5 & 9 \\
\hline $\mathrm{C}$ & 37 & 16.5 & 9.5 \\
\hline SL-A & 39 & 19 & 9 \\
\hline SL-B & 37 & 15.5 & 9 \\
\hline SL-C & 37 & 16.5 & 9.5 \\
\hline
\end{tabular}

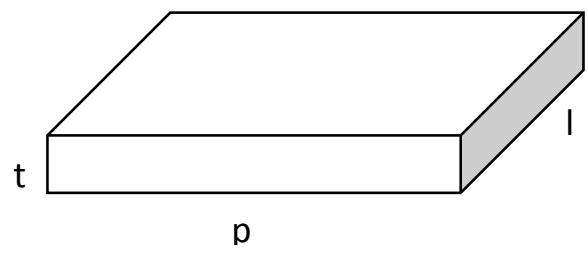

Fig 4. Dimension of brick specimen

Specimen material consisted of cement, sand, water, and honey (liquid form), and also natural polymers that are Gracilaria Sp.powder and Moringa oleifera powder. This research used Gracilaria Sp. powder that was manufactured product of gelatine powder (Fig 5) while Moringa oleifera powder was made by grinding raw Moringa oleifera seeds (Fig 6). The natural polymers added in during concrete mixing with cement, sand, and water.

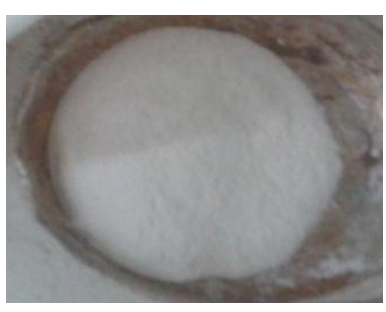

Fig 5. Gracilaria Sp. powder

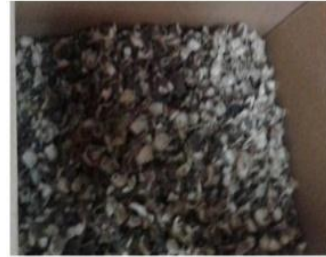

(a)

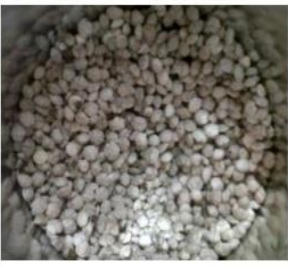

(b)

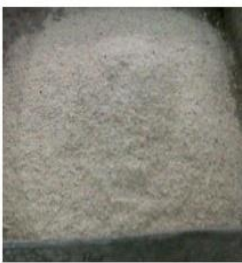

(c)
Fig 6. Raw Moringa oleifera

(1) raw material; (2) seeds without skin; (3) powder

\section{III.II. Mix-Design and Specimens Production}

Basic material mix design for specimen can be expressed by weight ratio of cement, sand, and water of $1: 1: 0.6=$ cement : sand : water, plus addition of natural polymers and honey. There were 2 (two) mix designs, the first used for PreExperiment stage (Table 2) and the second used for MainExperiment stage (Table 3). Compositions in MainExperiment were chosen from optimization of Pre-Experiment mix composition as well. Pre-Experiment specimens were produced first, and after the compressive strength test of them and got optimum result, the Main-Experiment brick specimens were produced later.

Table 2. Mix-Design of Pre-Experiment

\begin{tabular}{|c|c|c|c|c|c|c|}
\hline \multirow[t]{2}{*}{ series } & \multirow[t]{2}{*}{ specimen code } & \multirow{2}{*}{$\begin{array}{l}\text { brick } \\
\text { type }\end{array}$} & Gracilaria Sp. & honey & $\begin{array}{c}\text { Moringa } \\
\text { oleifera }\end{array}$ & \multirow{2}{*}{$\begin{array}{c}\text { total } \\
\text { number of } \\
\text { specimens }\end{array}$} \\
\hline & & & \multicolumn{3}{|c|}{$\%$ of cement weight } & \\
\hline $\mathrm{K}$ & $\mathrm{K}-\mathrm{A} ; \mathrm{K}-\mathrm{B} ; \mathrm{K}-\mathrm{C}$ & $\mathrm{A}, \mathrm{B}, \mathrm{C}$ & 0 & 0 & 0 & 15 \\
\hline $\mathrm{K} 1$ & K1-A; K1-B; K1-C & $\mathrm{A}, \mathrm{B}, \mathrm{C}$ & 0.05 & 0.03 & 0 & 15 \\
\hline $\mathrm{K} 2$ & K2-A; K2-B; K2-C & $\mathrm{A}, \mathrm{B}, \mathrm{C}$ & 0.1 & 0.03 & 0 & 15 \\
\hline K3 & K3-A; K3-B; K3-C & $\mathrm{A}, \mathrm{B}, \mathrm{C}$ & 0.025 & 0 & 0.075 & 15 \\
\hline $\mathrm{K} 4$ & K4-A; K4-B; K4-C & $\mathrm{A}, \mathrm{B}, \mathrm{C}$ & 0.1 & 0 & 0.1 & 15 \\
\hline SL & SL-A; SL-B; SL-C & $\mathrm{A}, \mathrm{B}, \mathrm{C}$ & N/A & N/A & N/A & 15 \\
\hline
\end{tabular}


Table 3. Mix-Design of Main-Experiment

\begin{tabular}{|c|c|c|c|c|c|c|}
\hline \multirow{2}{*}{ series } & \multirow{2}{*}{ specimen code } & \multirow{2}{*}{$\begin{array}{c}\text { brick } \\
\text { type }\end{array}$} & \multicolumn{2}{|c|}{ Gracilaria Sp. } & honey & \multicolumn{2}{|c|}{$\begin{array}{c}\text { Moringa } \\
\text { oleifera }\end{array}$} & $\begin{array}{c}\text { total } \\
\text { number of } \\
\text { specimens }\end{array}$ \\
\cline { 3 - 7 } & & & \multicolumn{2}{|c|}{$\%$ of cement weight } & 15 \\
\hline K1 & K1-A; K1-B; K1-C & A, B, C & 0.05 & 0.03 & 0 & 15 \\
\hline K3 & K3-A; K3-B; K3-C & A, B, C & 0.025 & 0 & 0.075 & 15 \\
\hline SL & SL-A; SL-B; SL-C & A, B, C & --- & --- & --- & 15 \\
\hline
\end{tabular}

\section{III.III. Compressive Strength Test}

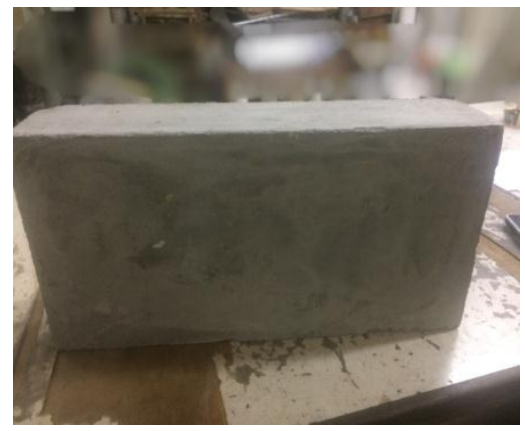

Fig 7. Concrete brick specimen

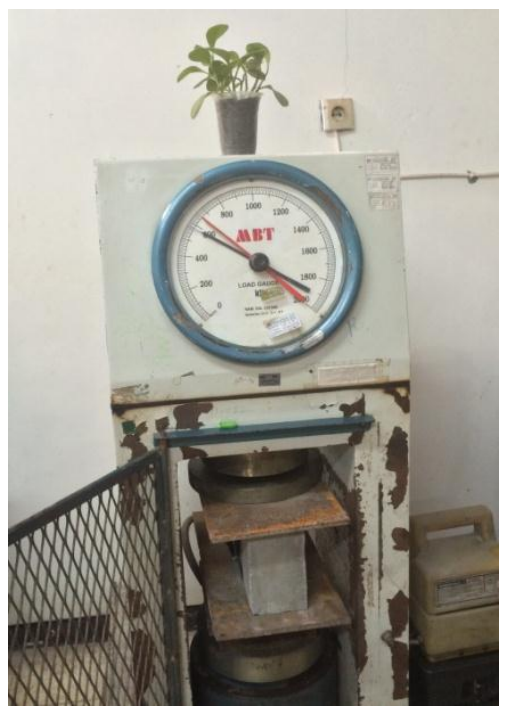

Fig 8. Set up specimen and Compressive Strength Test Machine

All specimens, (Fig 7) described by Table 2 (Pe-Experiment) and Table 3 (Main Experiment) were cured and tested in compressive strength based on SNI (Indonesian National Standard) No. 03-03449-1989 on "Concrete Brick for Masonry Wall". Compressive strength test was conducted by Compression Machine CO-325.4 (Fig 8) for concrete brick specimens at age 7, 14, and 28 days (for manufactured specimens only tested once, assumed at age 28 days). The manufactured products tested in compressive strength without curing.

Compressive strength of specimen (concrete brick) may be calculated by equation (1) as follow.

$$
\sigma=\frac{P}{A}
$$

Where:

$$
\begin{aligned}
& \sigma=\text { Compressive strength }(\mathrm{MPa}) \\
& \mathrm{P}=\operatorname{Load}(\mathrm{N}) \\
& \mathrm{A}=\text { Cross-sectional Area }\left(\mathrm{mm}^{2}\right)
\end{aligned}
$$

\section{FIELD APPLICATION}

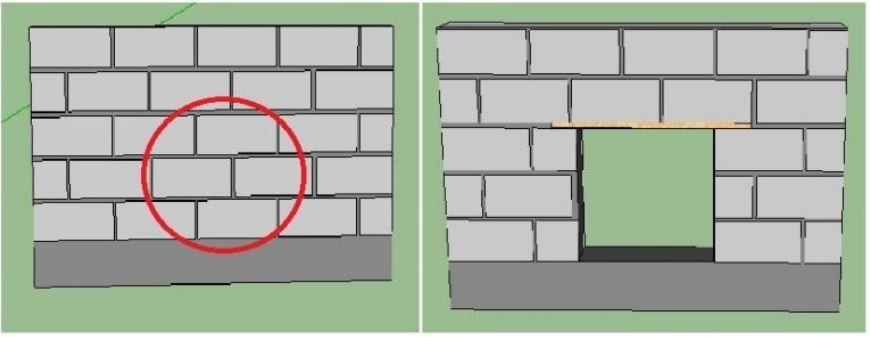

Fig 8. Illustration of concrete masonry wall retrofitting (a) Broken part of masonry wall; (b) Removed part of masonry wall

Field application was conducted in the end of 2016 after the optimum mix design and dimension of specimens have been found by previous laboratory test. The composition of K3-B was produced as concrete bricks for masonry wall retrofitting as shown by Fig 3b. After that, the broken part was selected to be retrofitted with procedure shown by Fig 9 . The broken part of masonry wall of $50 \mathrm{~cm} \times 50 \mathrm{~cm}$ in square was removed and then filled by concrete bricks (K3-B) and covered by mortar mix (Fig. 9). 

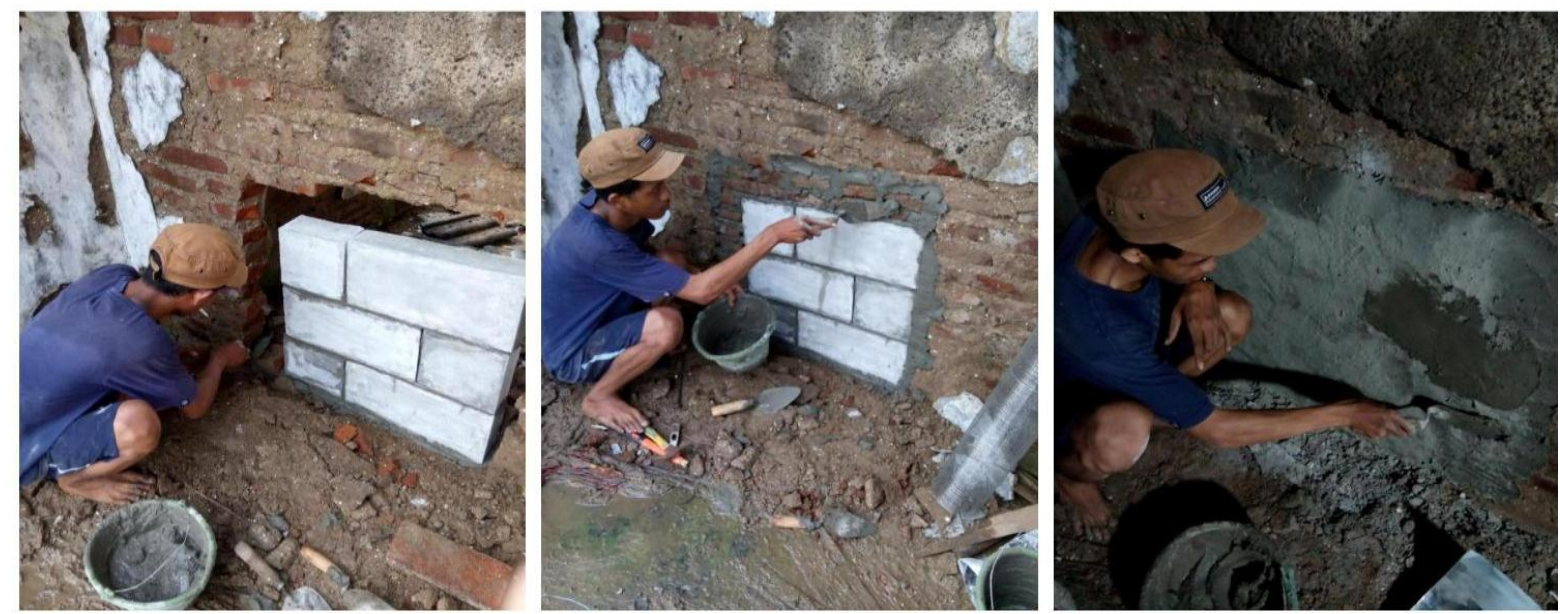

Fig 9. Retrofitting of masonry wall in site - (a) Filling the removed part by concrete bricks; (b) filling the space between new concrete bricks and the old masonry wall; (c) Plastering the retrofitted masonry wall

\section{CORE DRILL TEST}

Core Drill Test was carried out in nearly the end of 2017 in Sriwulan village and also in Pucang Gading village sites. This is a semi-destructive testing which referred to ASTM C 42/C 42M-04 Method for Obtaining and Testing Drilled Cores and Sawed Beams of Concrete, ACI 214.4R-03 Guide for Obtaining Cores and Interpreting Compressive Strength Results, and also Indonesia National Standard, SNI 03-24922002 Method of Obtaining and Testing Drilled Cores. Apparatus for obtaining the samples was a drill machine with diameter of 3 inch as shown by Fig 10 .

The cylinder specimens of Core Drill Test were taken out of the $0.5 \times 0.5 \mathrm{~m} 2$ of concrete masonry walls which was retrofitted part of broken masonry wall (Fig 11). Three core samples as described by Fig 11 were at point Q, R, and S which were aligned diagonally at the wall surface. Dimension of cylinder specimens of Core Drill Test described by Table 4 and Table 5.

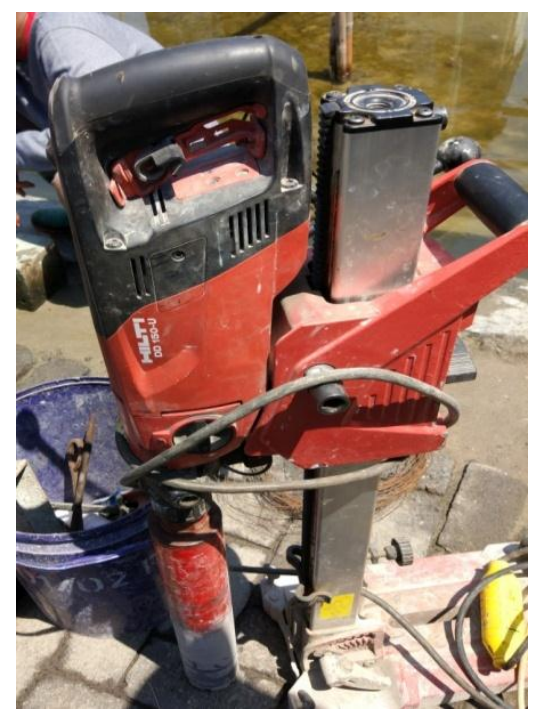

Fig 10. Core Drill Machine

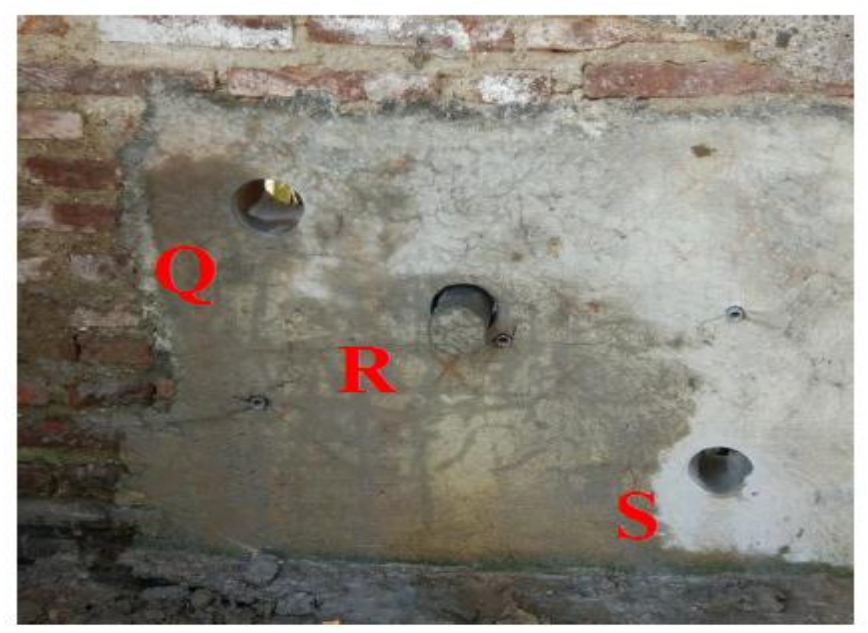

Fig 11. Core Drill sampling of retrofitted masonry wall

Core Drill specimens were tested for compressive strength at age 14 months by Computer Control Servo Hydraulic Concrete Compression Testing Machine, Hung-Ta HT 8391PC with Load Cell and Data logger as shown by Fig 12.

Compressive strength of Core Drill specimen may be calculated by equation (2)

$$
\sigma=\left\{\frac{P}{A} \times f_{l / d} \times f_{\text {dia }} \times f_{d}\right\}
$$

Where:

$$
\begin{aligned}
& \sigma=\text { Compressive strength }(\mathrm{MPa}) \\
& \mathrm{P}=\text { Load }(\mathrm{N}) \\
& \mathrm{A}=\text { Cross-sectional area }\left(\mathrm{mm}^{2}\right) \\
& \mathrm{f}_{1 / \mathrm{d}}=\text { Correction factor of ratio of length to diameter } \\
& \mathrm{f}_{\text {dia }}=\text { Correction factor of core diameter } \\
& \mathrm{f}_{\mathrm{d}}=\text { Correction factor of drilling }
\end{aligned}
$$




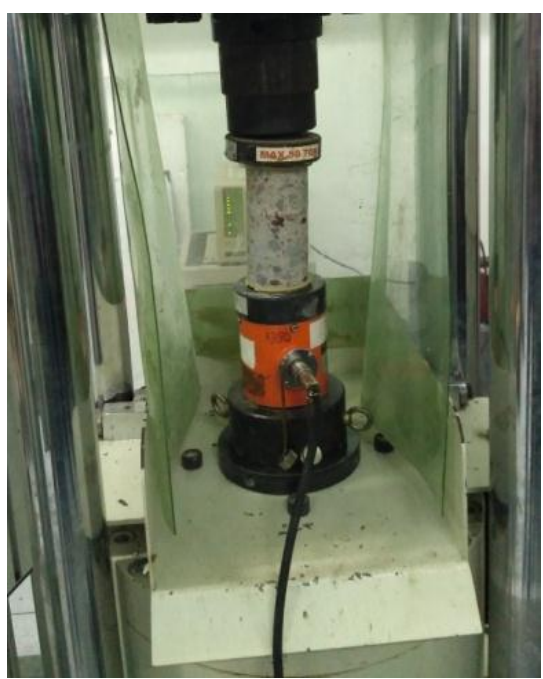

Fig 12. Computer Control Servo Hydraulic Concrete Compression Testing Machine

\section{RESULT}

\section{I. Compressive Strength of Concrete Brick Specimens}

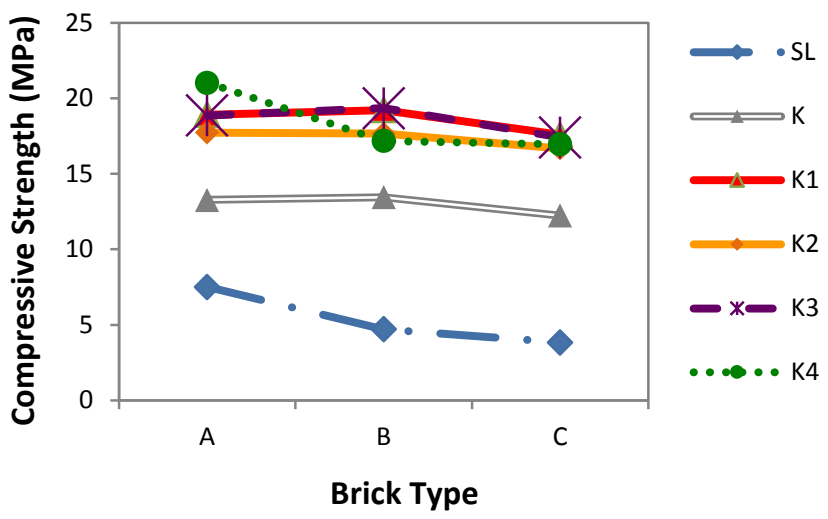

Fig 13. Compressive strength of specimens of Pre-Experiment stage

Pre-Experiment specimens were tested for compressive strength and clearly described by Fig 13 that product specimens (SL-A,B,C) have the lowest compressive stress (3.8 $\mathrm{MPa}$ to $7.5 \mathrm{MPa}$ ) followed by control specimens (12.25 $\mathrm{MPa}-13.45 \mathrm{MPa}$ ). Higher compressive stress achieved by K1, $\mathrm{K} 3$, and K4 brick specimens, about $16.67 \mathrm{MPa}-21.03 \mathrm{MPa}$. However, for K4 specimens, there was only K4-A reached the highest performance but not the others. It was obvious that the optimum compressive strength achieved by K1 and K3 series, then both of mix compositions used for Main-Experiment step.

For Main-Experiment stage, we investigated the compressive strength of brick specimens with series of $\mathrm{K}, \mathrm{K} 1$ and $\mathrm{K} 3$, at 7 , 14, and 28 days, as described by Fig 14, Fig 15, and Fig 16.

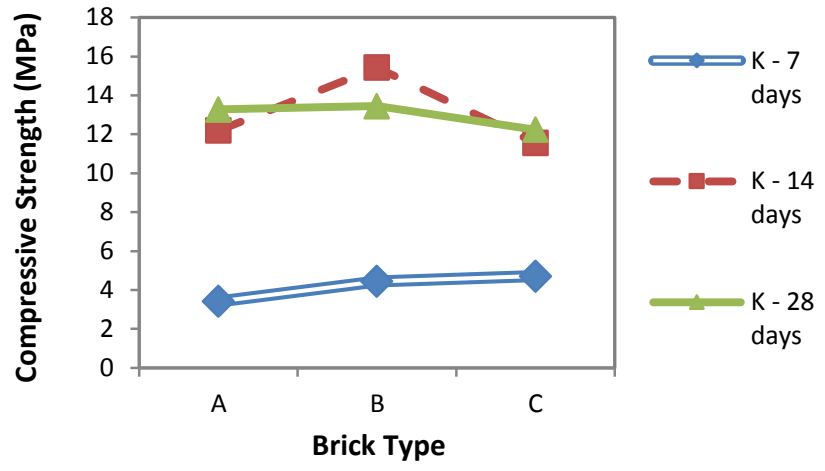

Fig 14. Compressive strength of $\mathrm{K}$ series of Main-Experiment stage at age 7,14 , and 28 days

Fig 14 described compressive strength development of $\mathrm{K}$ series. K-A seemed to have highest compressive strength (13.28 MPa) since its final compressive strength value at day 28 days was not decreasing as other specimens did. Specimens of A type had been reached highest value of compressive strength (15.88 MPa) in $\mathrm{K} 1$ series (Fig 15) and also in K3 series that highest compressive strength (16.13 $\mathrm{MPa}$ ) (Fig 16).

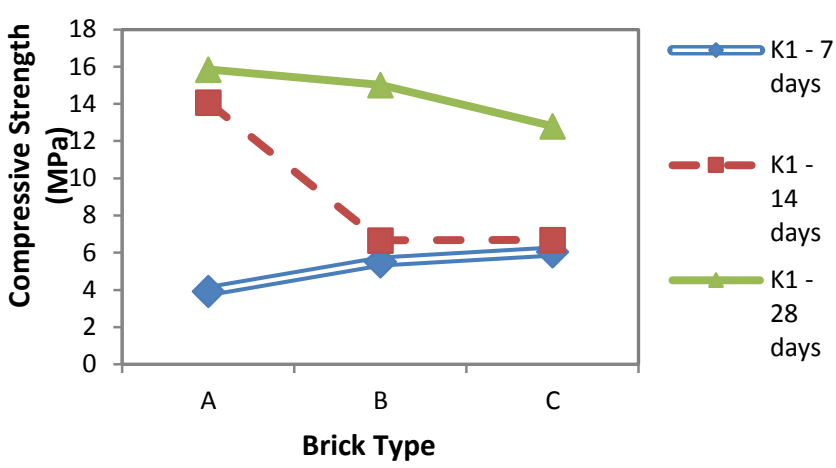

Fig 15. Compressive strength of K1 series of MainExperiment stage at age 7, 14, and 28 days

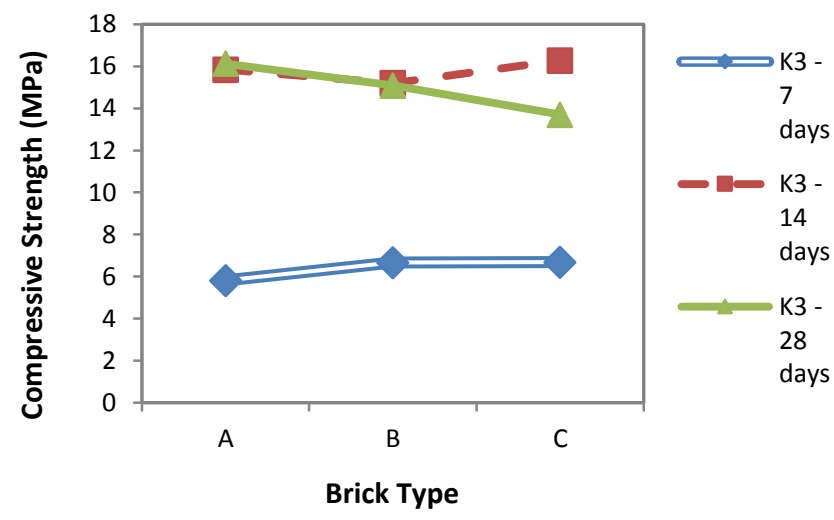

Fig 16. Compressive strength of $\mathrm{K} 3$ series of MainExperiment stage at age 7, 14, and 28 days 
Development of compressive strength of $\mathrm{K} 1$ series and K3 series performed good values, but K3 series has shown better performance it is optimum. K3 series had never shown decreasing of compressive strength but K1 series did, even a little bit dramatic at age 14 days. Hence, the optimum compressive strength is $\mathrm{K} 3$ series with A type. The production of bricks for field application then used K3-A composition for retrofitting the broken masonry wall.

\section{II. Compressive Strength of Core Drill Specimens}

Core drill specimens taken out of broken masonry wall in two sites, Pucang Gading village and Sriwulan village were cylinders as shown by Fig 17. Compressive strength of the specimen calculated by concerning several correction factors as detailed by Table 4 and Table 5 as it previously reported in [9].

Table 4. Core Drill Test Result for Specimens in Pucang Gading Village

\begin{tabular}{|c|r|r|r|r|r|r|r|r|r|r|}
\hline $\begin{array}{c}\text { specimen code } \\
\text { / core drill } \\
\text { point }\end{array}$ & $\begin{array}{c}\text { weight } \\
(\text { gram })\end{array}$ & $\begin{array}{c}\text { length } \\
(\mathrm{mm})\end{array}$ & $\begin{array}{c}\text { diameter } \\
(\mathrm{mm})\end{array}$ & $\begin{array}{c}\text { load } \\
(\mathrm{N})\end{array}$ & $\begin{array}{c}\text { cross } \\
\text { section } \\
\text { area } \\
(\mathrm{mm})\end{array}$ & L/D & $\begin{array}{l}\text { correction } \\
\text { factor } \\
\text { L/D }\end{array}$ & $\begin{array}{c}\text { correction } \\
\text { factor } \\
\text { diameter }\end{array}$ & $\begin{array}{c}\text { correction } \\
\text { factor } \\
\text { drilling }\end{array}$ & $\begin{array}{c}\text { compressive } \\
\text { strength } \\
(\mathrm{MPa})\end{array}$ \\
\hline P-D-B-01A / Q & 710 & 80 & 70 & 320620 & 3850 & 1.1429 & 0.9036 & 1.036 & 1.06 & $82.64 *$ \\
\hline P-D-B-02A / R & 700 & 80 & 70 & 125788 & 3850 & 1.1429 & 0.9036 & 1.036 & 1.06 & $32.64 *$ \\
\hline P-D-B-03A / S & 870 & 105 & 70 & 237472 & 3850 & 1.5 & 0.96 & 1.036 & 1.06 & $65.03 *$ \\
\hline
\end{tabular}

*Compressive strength value of $82.64 ; 32.64$; and 65.03 ; but details of Table 4 was excluded, have also been reported by authors in [9]

Table 5. Core Drill Test Result for Specimens in Sriwulan Village

\begin{tabular}{|c|r|r|r|r|r|r|r|r|r|r|}
\hline $\begin{array}{c}\text { specimen code } \\
\text { / core drill } \\
\text { point }\end{array}$ & $\begin{array}{c}\text { weight } \\
(\mathrm{gram})\end{array}$ & $\begin{array}{c}\text { length } \\
(\mathrm{mm})\end{array}$ & $\begin{array}{c}\text { diameter } \\
(\mathrm{mm})\end{array}$ & $\begin{array}{c}\text { load } \\
(\mathrm{N})\end{array}$ & $\begin{array}{c}\text { cross } \\
\text { section } \\
\text { area } \\
(\mathrm{mm} 2)\end{array}$ & L/D & $\begin{array}{c}\text { correction } \\
\text { factor } \\
\text { L/D }\end{array}$ & $\begin{array}{c}\text { correction } \\
\text { factor } \\
\text { diameter }\end{array}$ & $\begin{array}{c}\text { correction } \\
\text { factor } \\
\text { drilling }\end{array}$ & $\begin{array}{c}\text { compressive } \\
\text { strength } \\
(\mathrm{MPa})\end{array}$ \\
\hline S-D-B-01B / Q & 810 & 105 & 70 & 214020 & 3850 & 1.5 & 0.96 & 1.036 & 1.06 & $58.60^{*}$ \\
\hline S-D-B-02B / R & 790 & 105 & 70 & 214028 & 3850 & 1.5 & 0.96 & 1.036 & 1.06 & $58.61^{*}$ \\
\hline S-D-B-03B / S & 770 & 105 & 70 & 53628 & 3850 & 1.5 & 0.96 & 1.036 & 1.06 & $14.68^{*}$ \\
\hline
\end{tabular}

*Compressive strength value of 58.60; 58.61; and 14.68, but details of Table 5 was excluded, have also been reported by authors in [9]

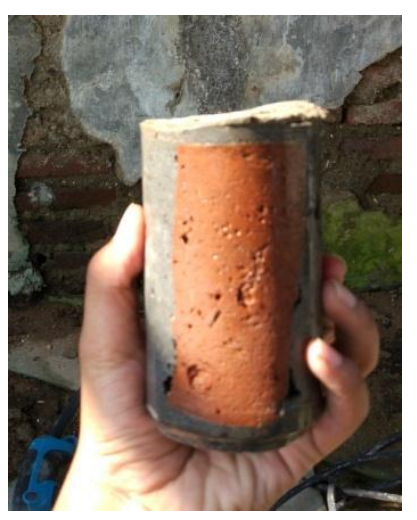

Fig 17. Core Drill specimen

Table 4 (Pucang Gading village) and Fig 17 have shown the lowest compressive strength at point R, P-D-B-02A was very low (31.22 MPa). This could be influenced by crack around the point that caused by anchor during drilling. However, the point S (Fig 11) has shown lower compressive strength $(65.03$ $\mathrm{MPa})$ compared to the compressive strength at point Q $(82.64$
$\mathrm{MPa}$ ). The little difference of compressive strength occurred because of the soil in the bottom of the masonry wall was moist.

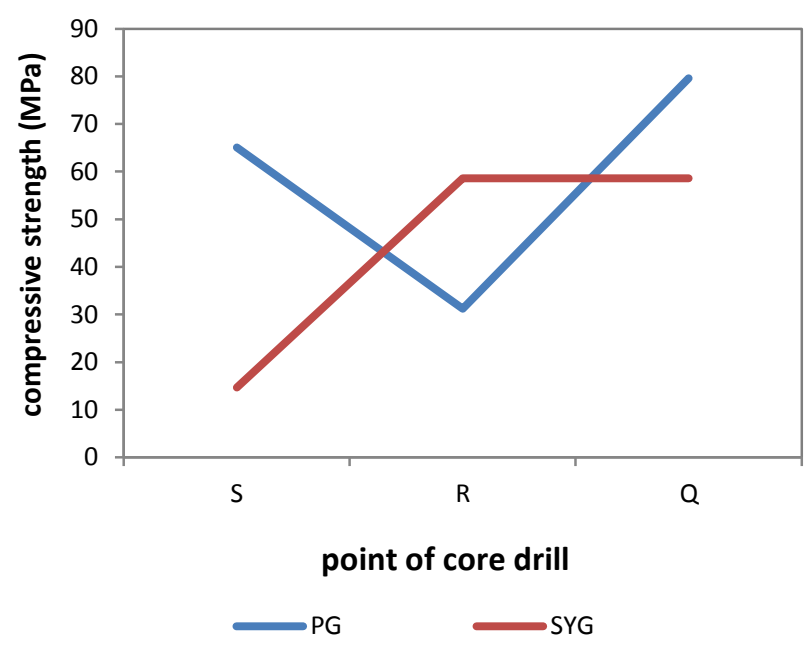

Fig 18. Compressive strength of Core Drill specimens 
Core drill specimens from Sriwulan village have shown different result because of the site is continuously submerged by tidal flooding, hence the environment becomes aggressive. Table 5 and Fig 18 have shown that lowest compressive strength (14.68 MPa) achieved by specimen taken out of point $\mathrm{S}$, in the bottom of the masonry wall, compared to other points (58.60 MPa and 58.61 MPa).

\section{DISCUSSION}

It is interesting that compressive strength of $\mathrm{K} 1$ and $\mathrm{K} 3$ series specimens only $40 \%$ compared to $\mathrm{K}$ as control specimens (Fig 18) while those series have very high compressive strength compared to SL (Fig 19), manufactured product (Fig 20), about $150-350 \%$ higher. K3-C series compressive strength was found $353.13 \%$ higher compared to SL. Therefore, the natural polymers of Moringa oleifera, Gracilaria Sp., and also honey, have contributed to increase the performance of concrete bricks by providing extra bond mechanism. As reported by [11], agarose and agaropectin in Gracilaria $S p$. provide strong gel that increase the bond mechanism of concrete brick. Previous researches [12][13] also noted that Moringa oleifera contains glycerol that has proven to increase bond and strength of mortar and concrete compressive strength. Addition of honey was also provided better bond mechanism since there was significant increase of compressive strength of $\mathrm{K} 1$ series. Therefore, the good performance of concrete bricks can be expressed by linear relation between $\mathrm{K} 1-\mathrm{K} 3$ series to $\mathrm{K}$ and SL with increment of compressive strength as described by Fig 20.

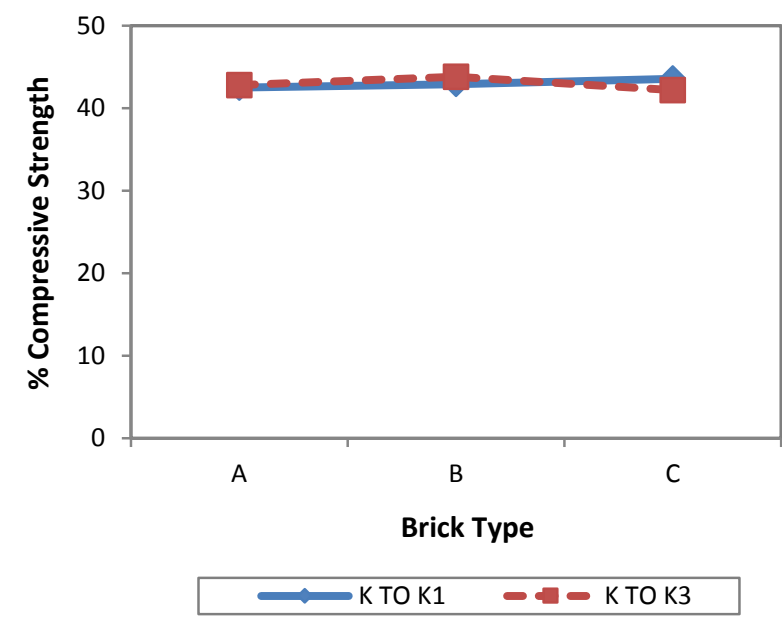

Fig 18. Comparative value of compressive strength between $\mathrm{K} 1-\mathrm{K} 3$ and $\mathrm{K}$

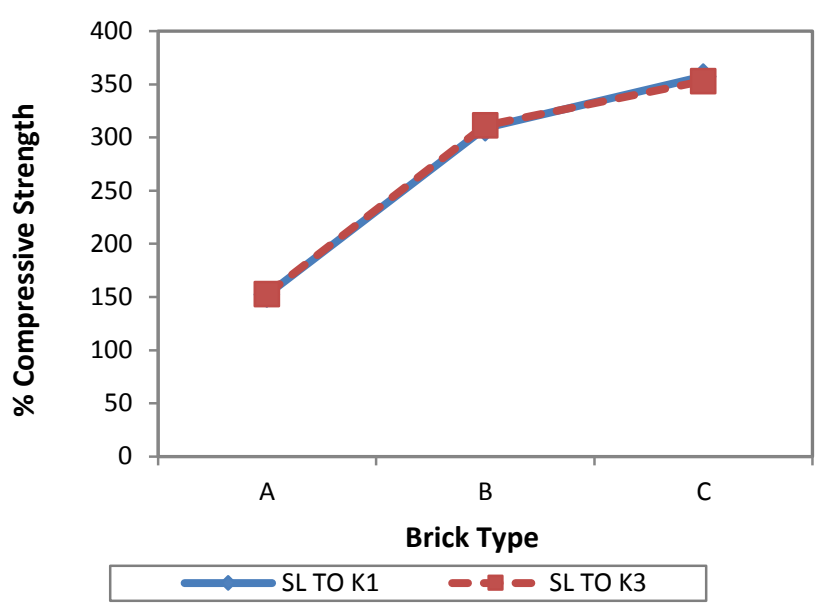

Fig 19. Comparative value of specimen compressive strength between $\mathrm{K} 1-\mathrm{K} 3$ and $\mathrm{SL}$

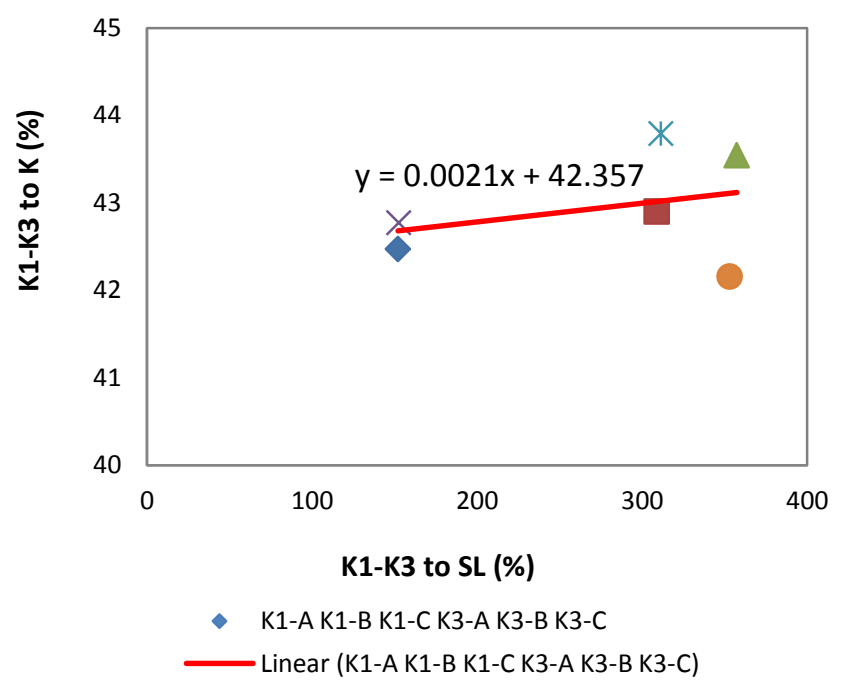

Fig 20. Relation between $\% \mathrm{~K} 1-\mathrm{K} 3$ to $\mathrm{K}$ to $\% \mathrm{~K} 1-\mathrm{K} 3$ to $\mathrm{SL}$

Good performance of concrete bricks shown by experiment results was also perform very satisfied in application to retrofit the broken masonry wall [15] as described by Fig 21. It is emphasized that core drill test specimens in Sriwulan village that continuously submerged by seawater perform good compressive strength from $77.42 \%$ to $26.34 \%$ compared to Pucang Gading specimens. The lowest value of compressive strength in Fig 21 was achieved by point $S$ that was suffered by great exposure of seawater because it was laid on the bottom of the concrete masonry wall. 


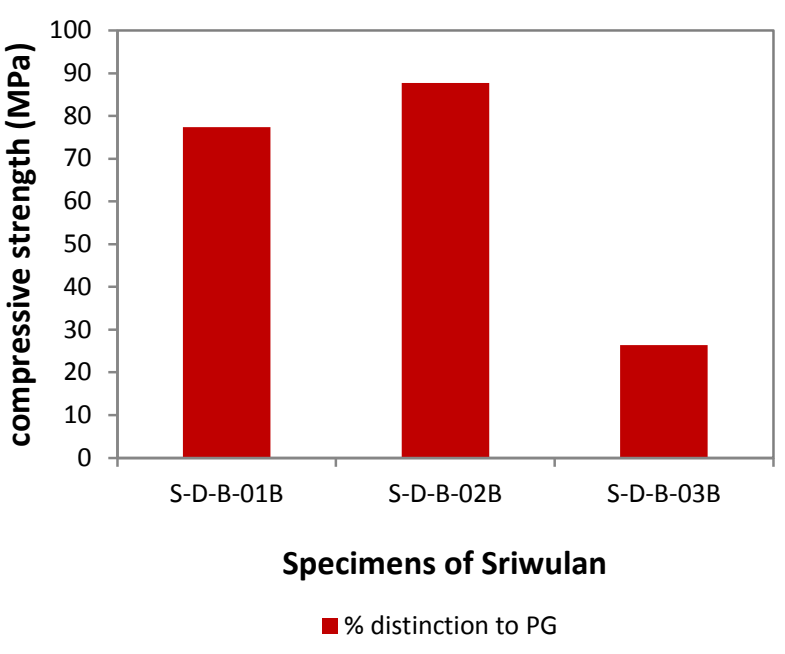

Fig 21. \% distinction of specimens Sriwulan to specimens Pucang Gading

Durability of concrete masonry wall was clearly defined by Fig 22. Compressive strength of 28 days old concrete brick with natural polymers increase about four times (73.84 MPa) when it is applied to concrete masonry wall in dry area of Pucang Gading village and about three times (58.61 MPa) in tidal flooding prone area of Sriwulan village at age 14 months. Eco-concrete bricks with natural polymers of Moringa oleifera, Gracilaria Sp., and also honey provide great performance in compressive strength increase.

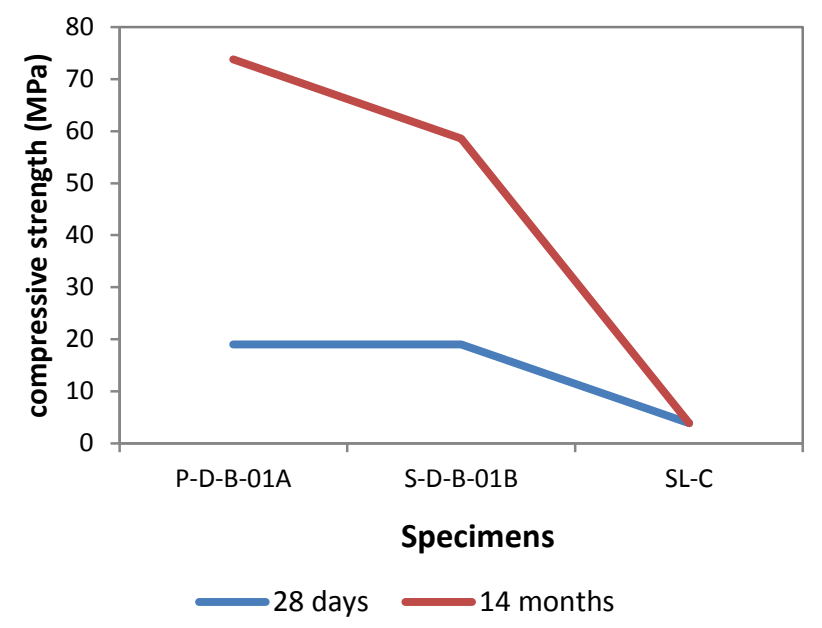

Fig 22. Comparison of compressive strength among specimens

\section{CONCLUSION}

The term of "Eco-Concrete Bricks" is suitable for concrete bricks with addition of natural polymers such as Moringa oleifera, Gracilaria Sp., and honey. K1 series and K3 series have shown good performance of strength, especially K3 series served optimum compressive strength as 16.13 MPa. Retrofitting of masonry wall with "Eco-Concrete Bricks" performed significant increase of four times (73.84 MPa) in Pucang Gading village and three times (58.61 MPa) in Sriwulan village of initial strength of concrete bricks

\section{ACKNOWLEDGMENT}

The authors gratefully acknowledge the funding from Ministry of Research, Technology, and Higher Education, Republic of Indonesia, by grants of Competency Research Grant 2014-2016 (Contract No. 052/K6/KL/SP/Penelitian/2014) and also INSINAS Riset Pratama Individu Grant 2017-2018) (Contract No. 35/INS/PPK/E/E4/2017 and No. 35/INS-1/PPK/E4/2018) which have supported this research and publication.

\section{REFERENCES}

[1] Singh, S.B., Munjal, P. Bond strength and compressive stress-strain characteristics of brick masonry. Journal of Building Engineering. 2017. 9(November). Pp. 10-16. DOI:10.1016/j.jobe.2016.11.006.

URL: http://dx.doi.org/10.1016/j.jobe.2016.11.006.

[2] Faella, C., Martinelli, E., Nigro, E., Paciello, S. Shear capacity of masonry walls externally strengthened by a cement-based composite material: An experimental campaign. Construction and Building Materials. 2010. 24(1). Pp. 84-93. DOI:10.1016/j.conbuildmat.2009.08.019. URL: http://dx.doi.org/10.1016/j.conbuildmat.2009.08.019.

[3] Tang, S.W., Yao, Y., Andrade, C., Li, Z.J. Recent durability studies on concrete structure. Cement and Concrete Research. 2015. 78. Pp. 143-154. DOI:10.1016/j.cemconres.2015.05.021.

[4] Medeiros, M.H.F., Gobbi, A., Réus, G.C., Helene, P. Reinforced concrete in marine environment: Effect of wetting and drying cycles, height and positioning in relation to the sea shore. Construction and Building Materials. 2013. 44. Pp. 452-457. DOI:10.1016/j.conbuildmat.2013.02.078. URL: http://dx.doi.org/10.1016/j.conbuildmat.2013.02.078.

[5] Melchers, R.E., Li, C.Q. Reinforcement corrosion initiation and activation times in concrete structures exposed to severe marine environments. Cement and Concrete Research. 2009. 39(11). Pp. 1068-1076. DOI:10.1016/j.cemconres.2009.07.003.

[6] Susilorini, R.M.I.R., Suwarno, D., Santosa, B., Putra, L.H., Kurniawan, E. Rebound Hammer Test result of old repaired masonry wall using premixed mortar additive in tidal flooding prone area. AIP Conference Proceedings. 2018. 1977(June). Pp. 1-6. DOI:10.1063/1.5042982.

[7] Susilorini, R.M.I.R., Rejeki, V.G.S., Santosa, B., Caresta, F.D., Putro, M.S. Polymer modified mortar with bonding adhesive agent for column repairing in 
tidal flooding prone area. AIP Conference Proceedings. 2018. 1977(June). DOI:10.1063/1.5042969.

[8] Susilorini, R.R.M.I.R., Vidayanti, D., Fitra, H.A., Santosa, B. Can we adapt to tidal flooding? AIP Conference Proceedings. 2019. 2114(June). DOI:10.1063/1.5112454.

[9] Hardian, L., Kurniawan, E., Retnosusilorini, R.M.I., Santosa, B. Efektivitas Uji Tidak Merusak Dan Uji Merusak Pada Dinding Bata Beton Hasil Perbaikan Dengan Additive Kimiawi Di Daerah Rawan Rob. Teknik Sipil Unika Soegijapranata Semarang |. 2018. 2. Pp. 2620-5297.

[10] Cerqueira, D.P., Portella, K.F., Portella, G.D.O.G., Cabussú, M., Machado, E.C., Da Silva, G.C., Brambilla, K.J.C., De Oliveira, D.R., Salles, R.N., Pereira, P.A.M., Henke, S.L., Inone, P.C., Ribeiro, S. Deterioration rates of metal and concrete structures in coastal environment of the South and Northeast Brazil: Case studies in the Pontal do Sul, PR, and Costa do Sauípe, Bahia. Procedia Engineering. 2012. 42. Pp. 384-396. DOI:10.1016/j.proeng.2012.07.430.

[11] Susilorini, R.M.I.R., Hardjasaputra, H., Sri, T., Galih, H., Reksa, W.S., Ginanjar, H., Joko, S. The advantage of natural polymer modified mortar with seaweed: Green construction material innovation for sustainable concrete. Procedia Engineering. 2014. 95. DOI:10.1016/j.proeng.2014.12.201.

[12] I Retno Susilorini, R.M., Santosa, B., Sri Rejeki, V., Devita Riangsari, M., Hananta, D. The Advantage of Moringa oleifera Powder Addition in Natural Polymer Modified Concrete Mixture. 2017. 1. Pp. 10-14. URL: http://stseed.weebly.com/uploads/3/1/9/7/3197.

[13] Susilorini, R.M.I.R., Santosa, B., Rejeki, V.G.S., Riangsari, M.F.D., Hananta, Y.D. The increase of compressive strength of natural polymer modified concrete with Moringa oleifera. AIP Conference Proceedings. 2017. 1818. DOI:10.1063/1.4976923.

[14] Rr. M. I. Retno Susilorini, Budi Santosa, N. Febri Satrio, R.P.B. Compressive and Splitting Tensile Strength of Polymer Modified Concrete Using Amylum and Honey. Journal of Engineering and Applied Science. 2018. 13(17). Pp. 7192-7197. DOI:http://dx.doi.org/10.3923/jeasci.2018.7192.7197.

[15] William S, S., Rianto. Compressive Strength of Solid Bricks with Natural Polymer of Gracilaria Sp., Moringa oleifera, and Honey Admixture (Kuat Tekan Bata Beton Pejal dengan Polimer Alami Gracilaria Sp. dan Moringa oleifera serta Bahan Tambah Madu). Undergraduate Thesis, Department of Civil Engineering, Faculty of Engineering, Soegijapranata Catholic University, Semarang, Indonesia, 2018. 